\title{
CARCINOMA OF THE LUNG SIMULATING EARLY RHEUMATOID ARTHRITIS
}

\author{
BY \\ K. A. J. JÄRVINEN and T. KUMLIN \\ From the Third Medical Clinic of the University of Helsinki, Finland
}

(RECEIVED FOR PUBLICATION DECEMBER 14, 1953)

It is well known that lung affections may be accompanied by so-called hypertrophic pulmonary osteo-arthropathy, which seems to be almost regularly associated with mild joint symptoms. Bamberger (1889) and Marie (1890) first studied this syndrome, but little attention has been paid to the misleading resemblance of these joint symptoms to those seen in the early stages of rheumatoid arthritis, though individual cases appear in the literature (Craig, 1937; Fried, 1943; Ellman, 1947; Pattison and others, 1951; and Frank, 1952).

It was our main object to investigate how frequently the clinician finds difficulty in the differential diagnosis of the joint symptoms accompanying carcinoma of the lung.

\section{Material}

The first series included 1,008 patients (725 female and 283 male) hospitalized in the clinic from 1934 to 1948 under the diagnosis of rheumatoid arthritis. The average age was 50 years for the females and $45 \cdot 1$ years for the males. A closer analysis was made of the patients with lung infiltration, pneumonia, and similar affections, and with a history of rheumatoid arthritis of not more than 5 years' duration at the time of onset of the pulmonary changes. This period was considered sufficiently long to exclude carcinoma of the lung.
The second series comprised 106 patients (27 females and 79 males) hospitalized for carcinoma of the lung from: 1949 to 1951 . The average age was $60 \cdot 2$ years for the $\omega$ females, and 63.6 years for the males. A more detailedstudy was made of the cases with definite joint symptoms N accompanied by objective articular changes.

\section{Results}

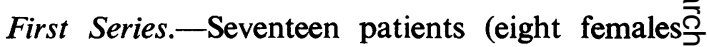
and nine males) were found with lung infiltration $\overrightarrow{0}$ and a history of joint symptoms for not morecr than 5 years at the time of recognition of the pulmonary changes. The examinations excludedo primary carcinoma of the lung in all but three of them. A diagnosis of atypical pneumonia or itso complication was made in five cases; in a further five $\frac{0}{\circ}$ cases the lung infiltration was demonstrated to beo tubercular. In one of the male cases there were $\overrightarrow{\hat{O}}$ metastases in the lungs from a carcinoma of the 3 prostate. Severe bronchiectasis and amyloidosis were present in one case.

One patient excluded from this series had suffered@ for about 10 years from rheumatoid arthritis, and then the onset of carcinoma of the lung was accom-3 panied by an exacerbation of the joint symptoms.

The three cases of carcinoma of the lung with

TABLE

CASES TREATED FOR RHEUMATOID ARTHRITIS IN WHICH THE CLINICAL PICTURE WAS LATER FOUND TO BE DUE TO BRONCHIAL CARCINOMA

\begin{tabular}{|c|c|c|c|c|c|c|c|c|}
\hline Series & $\begin{array}{l}\text { Case } \\
\text { No. }\end{array}$ & Sex & $\begin{array}{c}\text { Age at onset of } \\
\text { rheumatoid } \\
\text { arthritis } \\
\text { symptoms } \\
\text { (yrs) }\end{array}$ & $\begin{array}{l}\text { Duration of } \\
\text { joint and other } \\
\text { rheumatoid } \\
\text { arthritis } \\
\text { symptoms before } \\
\text { recognition of } \\
\text { carcinoma } \\
\text { (mths) }\end{array}$ & $\begin{array}{c}\text { Erythrocyte } \\
\text { sedimentation } \\
\text { rate on } \\
\text { hospitalization } \\
(\mathrm{mm} . / \mathrm{hr})\end{array}$ & $\begin{array}{l}\text { Haemoglobin } \\
\text { (per cent.) }\end{array}$ & $\begin{array}{c}\underset{\text { Maximum }}{\text { body }} \\
\text { temperature } \\
\left({ }^{\circ} \mathrm{C} .\right)\end{array}$ & $\begin{array}{l}\text { Time from onset } \\
\text { of rheumatoid } \\
\text { arthritis } \\
\text { symptoms } \\
\text { to death } \\
\text { (mths) }\end{array}$ \\
\hline & & & $\begin{array}{c}54 \\
\text { (symptoms at } 35)\end{array}$ & & 55 & pale & $39 \cdot 7$ & 7 \\
\hline 1 & $\begin{array}{l}2 \\
3\end{array}$ & $\begin{array}{l}\mathbf{M} \\
\mathbf{M}\end{array}$ & $\begin{array}{l}57 \\
57\end{array}$ & $\begin{array}{l}7 \\
3\end{array}$ & $\begin{array}{l}105 \\
108\end{array}$ & $\begin{array}{l}68 \\
65\end{array}$ & $\begin{array}{l}37 \cdot 8 \\
37 \cdot 7\end{array}$ & $\begin{array}{r}24 \\
7\end{array}$ \\
\hline 2 & $\begin{array}{l}4 \\
5\end{array}$ & $\begin{array}{l}\mathbf{M} \\
\mathbf{M}\end{array}$ & $\begin{array}{l}51 \\
57\end{array}$ & $\begin{array}{l}7 \\
8\end{array}$ & $\begin{array}{r}61 \\
122\end{array}$ & $\begin{array}{c}78-68 \\
57\end{array}$ & $\begin{array}{l}38 \cdot 3 \\
38 \cdot 0\end{array}$ & $\begin{array}{r}7 \\
20\end{array}$ \\
\hline
\end{tabular}


arthritic symptoms are included in the Table (Cases 1-3).

Second Series.-Five patients showed a clinical picture resembling rheumatoid arthritis; in three of these the onset of rheumatoid arthritis had occurred 5,11 , and 15 years respectively before the tumour was recognized, and no aetiological connection between the two diseases seems probable. On the other hand, there was a simultaneous onset of symptoms in two cases, which are shown in the Table (Cases 4 and 5).

The diagnosis of carcinoma of the lung was definitely established in the five cases listed in the Table, yet all the patients complained of very considerable pain in the affected joints, and had originally consulted a physician for this reason. In all cases there was active swelling of the joints, the articular regions were febrile, movements were markedly restricted, and muscular atrophy was present especially in the small muscles of the upper extremities, but additional features deviated from the typical rheumatoid arthritis syndrome. Cough symptoms had been present in all cases before the joint affection, but were too mild to be considered an inconvenience. Chest $x$ rays eventually revealed the presence of a lung process, but in Case 4 the first $x$-ray examination gave a negative result and the erroneous diagnosis was therefore retained for some time. Acromegalic features developed in two cases; this was by no means a coincidence, for the same observation has been made by others. Fried (1943) described four cases, in three of which definite eosinophilic cell hyperplasia of the hypophysis was found at autopsy. In our own series the post-mortem hypophyseal finding in Case 4 was also of the acromegalic type. The sex incidence also differs from that of rheumatoid arthritis. Palmar erythema was a common finding in our patients, but this affection is not rare in rheumatoid arthritis, and Jonsson (1952) regards it as a symptom of that disease.

\section{Case Report}

Case 4, a labourer, 51 years of age, was admitted to hospital on January 10,1952, with joint symptoms of one month's duration. He complained of poor appetite and an indefinite distress in the stomach. He believed he had lost about $4 \mathrm{lb}$. in weight. Achylia was present, he admitted to an insignificant "smoker's cough" of about 3 months' duration, and his feet, hands, and lower jaw had much increased in size. The large and small joints of the extremities had all become painful and swollen, and the temperature was raised to $37.5^{\circ}$ and $39^{\circ} \mathrm{C}$.

Examination.-The face appeared acromegalic, the lower jaw being protruded, the cheekbones prominent, and the soft tissues of the ears and nose thick. The hands

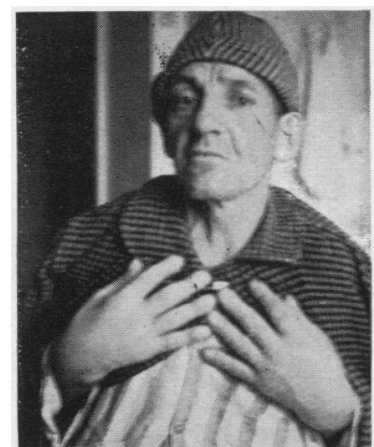

Figure.-Case 4, showing clubbed fingertips, swollen finger joints, and acromegaly.

were large and spade-like (Figure). The joints most severely affected were both ankles, left knee (marked accumulation of synovial fluid), both wrists, right elbow, and phalangeal joints especially middle and proximal joints of the second and fourth fingers. The articular regions were swollen and hot, and movement was painful and restricted. Apart from these symptoms simulating rheumatoid arthritis, there was redness of the tips of fingers and toes, increased growth of their soft parts, and slight biconcavity and tenderness of the nails.

Auscultation and percussion of the lungs yielded no pathological findings. Lung function appeared normal: vital capacity, 3.75 1.; complementary air, 1.87 1.; reserve air, 0.94 1.; tidal air, 0.94 1.; maximum respiration, $108 \mathrm{l}$./min. (92 per cent. of normal).

There was no cardiac abnormality. The blood pressure was $140 / 88 \mathrm{~mm}$. $\mathrm{Hg}$.

Radiology. $-X$ ray showed scars of a surgical operation for the removal of a knife-point from the lower portion of the right lung, slight hypertrophy of the heart, and bilateral defective development of the first rib. The hilar regions did not appear to be pathologically involved. The joints showed changes typical of incipient arthritis, with periosteal thickening and calcification of the ulna, radius, and metacarpal bones. The sella turcica appeared slightly above normal size.

\section{Laboratory Findings}

Erythrocyte sedimentation rate $61 \mathrm{~mm}$./hr.

Gonococcal complement-fixation test negative; Wasserman reaction negative.

Antistreptolysin $O$ titre 1:160.

Total serum protein 8 per cent. (albumin $3 \cdot 2$, globulin 4.8).

Formol-gel test positive in plasma in $5 \mathrm{~min} .12 \mathrm{sec}$; negative in serum.

Blood sugar $100 \mathrm{mg}$. per cent.

Haemoglobin $12.05 \mathrm{~g}$.; erythrocytes 4.3 million per c.mm.; leucocytes 11,300 per c.mm.; eosinophils 1.5 per cent.; neutrophil staff cells 1.0 per cent.; neutrophil polymorphonuclears 51.5 per cent.; lymphocytes $36 \cdot 0$ percent.; monocytes $9 \cdot 5$ percent.

Platelets 307,000 per c.mm.

Rest nitrogen $20 \mathrm{mg}$. per cent.

Urine analysis normal.

Electrocardiogram normal.

Field of vision normal. 
Ninety drops tinct. belladonna caused a transient, marked aggravation of the joint symptoms with elevation of body temperature in $24 \mathrm{hrs}$, similar to the reaction of rheumatoid arthritis patients to large amounts of atropine (Järvinen, 1952).

The joint symptoms progressed and the patient's condition deteriorated more rapidly than is usual in rheumatoid arthritis; after 6 weeks he became highly febrile, with increasingly active joint symptoms. When the danger of ankylosis became apparent, the parenteral administration of cortisone was started, and the symptoms were rapidly allayed at first, but a daily dose of not less than $100 \mathrm{mg}$. was unable to prevent recurrence of the inflammatory symptoms. As the clubbing of the fingers and toes continued to progress, another radiological examination of the lungs was carried out. The presence of a tumour in the left hilar region was suspected, but bronchoscopy failed to establish the suspicion, and biopsy also gave a negative result. The patient failed rapidly, the anaemia increased in spite of blood transfusions, and he died on June 18.

Post mortem.-A large carcinoma with infiltration of the intrathoracic lymph nodes was found in the upper lobe of the left lung. An intact bronchial mucosa explained the negative bronchoscopic finding. The appearance of the hypophysis pointed to acromegaly, cellular degeneration was evident throughout the gland, with poor differentiation of the acidophilic cells; haemorrhages, haemoglobinogenic pigment, and oedema were present in the stroma; the cells were atrophic; no signs of a tumour were observable in the hypophysis.

\section{Discussion}

It is apparent that pulmonary osteo-arthropathy developing on the base of a carcinoma of the lung may cause difficulty in recognizing the true condition. Our investigation showed that three of a total of 1,008 cases ( 1 per cent. of the patients over 50 years old) treated for rheumatoid arthritis had carcinoma of the lung. Similarly, two of 106 known cases of carcinoma of the lung had at first been treated for rheumatoid arthritis. Hansen (1952) found joint symptoms in twelve out of 100 patients with carcinoma of the lung, and Alvarez (1948) reported a greater prevalence of mild joint symptoms than of bronchial symptoms. A careful examination should ke made of the lungs of every patient who seeks medical aid with the clinical picture of early rheumatoid arthritis.

The clinical picture in such cases resembles idiopathic rheumatoid arthritis to such a degree that the question may be raised of a possible aetiological correlation of the arthritic conditions. The simultaneous occurrence of arthritic symptoms and carcinoma of the lung is evidently not a coincidence. Cases have also been reported in which the joint symptoms disappeared after successful surgical removal of a tumour of the lung (Brea, 1948; Alvarez, 1948; Hansen, 1952; Pavlovsky, 1947; 을 Rottjer and others, 1946; Ellman, 1947; Frank, 1952). This observation indicates that the joint $\stackrel{\vec{\rho}}{\vec{g}}$ affections cannot be ascribed to metastases, and no 0 metastatic tumours have been found in the joints on post-mortem examinations.

It seems probable that the rapid development of $\mathbb{D}$ the lung process plays some part in the occurrence of the joint symptoms. The clubbing of fingers and ${ }^{\circ}$ toes associated with slowly developing lung processes $\overrightarrow{0}$ and certain diseases of the heart is not accompanied $\overrightarrow{\vec{\omega}}$ by joint symptoms, though it seems probable that $\stackrel{\omega}{\sigma}$ the clubbing itself is a mild form of pulmonary osteo-arthropathy.

The aetiological mechanism of pulmonary osteo- $\vec{\omega}$ arthropathy and of the associated articular symptoms $\overrightarrow{i r}$ still remains obscure. Many investigators suggest $N$ a close connexion with neurogenic reflexes. Thus it has been observed that hilar neurotomy (without $\vec{r}$ resection of the lung) allays the joint symptoms in these patients for as much as 6 months (Brea, 1948; $\stackrel{\bar{a}}{9}$ Hansen, 1952). A similar effect has been found to follow the ligation of the pulmonary artery $\vec{f}$ (Wyburn-Mason, 1948). It is well to remember in + this connexion, however, that temporary recovery from rheumatoid arthritis has often been observed after major surgical operations on any part of the body. The possible role of the autonomic nervous

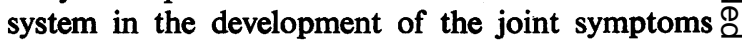
should also be considered, since severe symptoms $\overrightarrow{\vec{F}}$ sometimes appear in the joints of the corresponding $\frac{}{3}$ upper extremity in connection with periarthritis humeroscapularis and with cardiac infarction, pre-? sumably arising by way of reflex.

An analysis of the joint symptoms of patients with pulmonary osteo-arthropathy should also take $\frac{\bar{\sigma}}{3}$ into consideration the effect of possible hormonal:disorders. Disturbed hypophyseal function is frequently reflected in such symptoms as acromegalic features, but on the other hand joint symptoms are $\stackrel{\circ}{-}$ frequently present with acromegaly, and the simul- $D$ taneous occurrence of acromegaly and rheumatoid arthritis was reported by Jeanneney (1936). N

\section{Summary}

This report covers 1,008 patients diagnosed as ${ }^{\omega}$ suffering from rheumatoid arthritis and 106 patients with bronchial carcinoma. In the rheumatoide arthritis group, a follow-up examination indicated $\Phi$ that a bronchial carcinoma was probably the aetiological factor in the joint symptoms in three $\frac{0}{0}$ cases $\left(0 \cdot 3\right.$ per cent.; 1 per cent. of the patients over $\frac{1}{\mathbb{D}}$ 50 years of age). The bronchial carcinoma group $\frac{\text { P }}{\mathbb{D}}$ included two patients who had previously been $\varrho$ 
treated for rheumatoid arthritis, although the symptoms were probably caused by the lung process.

These findings indicate the importance of examining the lungs of patients presenting the symptoms of rheumatoid arthritis. In male patients with arthritic symptoms combined with acromegalic features and/or clubbing of the fingers and toes, carcinoma of the lung should always be suspected.

\section{REFERENCES}

Alvarez, G. H. (1948). Abs. in J. Amer. med. Ass. (1949), 140, 364

Bamberger, E. (1889). Wien. Klin. Wschr., 2, 226.

Brea, M. M. (1948). Cited in "Year Book of General Surgery, 1948", p. 307. Year Book Publishers, Chicago

Craig, J. W. (1937). Brit. med. J., 1, 750.

Ellman, P. (1947). Lancet, 1, 464.

Frank, H. A. (1952). New Engl. J. Med., 247, 283.

Fried, B. M. (1943). Arch, intern. Med. $72,565$.

Hansen, J. L. (1952). Acta med. scand., Suppl. 266, 467.

Jeanneney, G. (1936). Rev. Rhum., 3,33.

Jonsson, E. (1952). Nord. Med., 48, 1221.

Järvinen, K. A. J. (1952). Ann. Med. intern. Med., 41, 177.

Marie, P. (1890). Rév. Médecine, 10, 1.

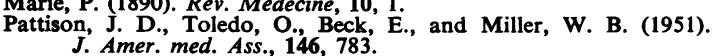

Pavlovsky, A. J. (1947). Cited in "Year Book of General Surgery, 1948", p. 306. Year Book Publishers, Chicago.

Rottjer, E. A., Aguilar, H., and Lascalea, M. C. (1946). Rev. Sanid. milit. (B. Aires), 45, 1163. Cited by Wyburn-Mason (1948).

milit. (B. Aires), 45, 1163. Cited by
Wyburn-Mason, R. (1948). Lancet, 1, 203.

\section{Carcinome du' poumon simulant le début d'une arthrite rhumatismale}

\section{RÉSUMÉ}

Ce rapport comporte 1008 malades diagnostiqués comme souffrant d'arthrite rhumatismale et 106 malades atteints de carcinome bronchique. Dans le groupe rhumatismal un examen ultérieur indiqua qu'un carcinome bronchique était probablement à l'origine des symptômes articulaires dans trois cas $(0,3 \%-1 \%$ des malades âgés de plus de 50 ans). Dans le groupe des carcinomes bronchiques se trouvaient deux malades qui avaient été traités pour une arthrite rhumatismale bien que leur symptômes auraient pu relever de processus pulmonaire.

Ces donnés indiquent l'importance de l'examen des poumons des malades présentant des symptômes d'arthrite rhumatismale. Chez un homme, des symptômes d'arthrite associés aux traits acromégaliques et/ou à la deformation noueuse des doigts et des orteils, devraient toujours faire penser à un carcinome pulmonaire.

\section{Carcinoma del pulmón simulando una artritis reumatoide temprana \\ SUMARIO}

Este informe comporta 1008 enfermos con el diagnóstico de artritis reumatoide y 106 enfermos con carcinoma bronquial. En el grupo reumático un examen ulterior indicó que un carcinoma bronquial constituyó probablemente el factor etiológico de los síntomas articulares en tres casos (el 0,3\%-1\% de los enfermos de más de 50 años de edad). En el grupo de los carcinomas bronquiales hubo dos enfermos que habían sido tratados por una artritis reumatoide aunque sus síntomas debiéranse probablemente al proceso pulmonar.

Estos resultados indican la importancia de examinar los pulmones de los enfermos que presentan síntomas de artritis reumatoide. En un hombre con síntomas de artritis asociados con rasgos de acromegalia y/o con dedos nodosos hay que sospechar un carcinoma pulmonar. 